\title{
Cesiribacter andamanensis gen. nov., sp. nov., isolated from a soil sample from a mud volcano
}

Correspondence

S. Shivaji

shivas@ccmb.res.in
The systematics of the family 'Flammeovirgaceae' are currently in a state of expansion, with many new genera being described within the last 6 years, including Fabibacter, Limibacter, Marinoscillum, Perexilibacter, Rapidithrix, Reichenbachiella, Marivirga and Roseivirga, from a wide variety of habitats such as decayed wood, sea shells (Srisukchayakul et al., 2007), fresh water (Nedashkovskaya et al., 2010), marine algae (Nedashkovskaya et al., 2005a; Srisukchayakul et al., 2007), sediment (Yoon et al., 2007, 2008), sponges (Lau et al., 2006; Seo et al., 2009) and seawater (Nedashkovskaya et al., 2005b). In the present study, we describe a novel bacterium isolated from a soil sample collected from a mud volcano that is assigned to a new genus that belongs to the family 'Flammeovirgaceae'.

Strain $\mathrm{AMV}^{\mathrm{T}}{ }^{\mathrm{T}}$ was isolated from a soil sample collected from a mud volcano on Baratang Island, Middle Andamans, India, on 20 February 2009. The sample that yielded strain $\mathrm{AMV} 16^{\mathrm{T}}$ had a $\mathrm{pH}$ of 7.5. For isolation of

The GenBank/EMBL/DDBJ accession number for the 16S rRNA gene sequence of strain $\mathrm{AMV}^{\mathrm{T}} 6^{\top}$ is FN396961. bacteria, $100 \mathrm{mg}$ soil sample was plated on ZoBell marine agar medium (ZoBell, 1941) and incubated at room temperature for 15 days. Based on colony morphology, a pale-orange colony was selected and characterized in the present study.

Flexibacter tractuosa DSM $4126^{\mathrm{T}}$ (now reclassified as Marivirga tractuosa, the type species of the genus Marivirga; Nedashkovskaya et al., 2010) was procured from the DSMZ; strain AMV16 ${ }^{\mathrm{T}}$ was characterized simultaneously with Marivirga (Flexibacter) tractuosa DSM $4126^{\mathrm{T}}$. Cell morphology and motility were studied using a light microscope. Motility was assessed on TSA containing $\left(\mathrm{l}^{-1}\right)$ pancreatic digest of casein $(17 \mathrm{~g})$, papaic digest of soybean meal $(3 \mathrm{~g}), \mathrm{NaCl}(5 \mathrm{~g})$, dipotassium hydrogen phosphate $(2.5 \mathrm{~g})$, glucose $(2.5 \mathrm{~g})$ and agar $(0.4 \mathrm{~g})$ and on motility indole lysine agar slants (cat. no. SL033; HiMedia). Growth at 4, 10, 18, 30, 37 and $40{ }^{\circ} \mathrm{C}$ and salt tolerance [0 (without $\mathrm{NaCl}$ ), 1, 2, 3, 4, 5, 6, 8 and $10 \%(\mathrm{w} / \mathrm{v}) \mathrm{NaCl}]$, biochemical characteristics, carbon assimilation, $\mathrm{H}_{2} \mathrm{~S}$ production and sensitivity of the culture to antibiotics were determined by previously described 
methods (Lányí, 1987; Smibert \& Krieg, 1994). Biochemical characteristics were confirmed with the Hi25 Enterobacteriaceae identification kit (cat. no. KB003) and HiCarbohydrate kit parts A, B and C (cat. no. KB009) (HiMedia) according to the manufacturer's protocol. Growth of strain $\mathrm{AMV}^{\mathrm{T}}{ }^{\mathrm{T}}$ at $\mathrm{pH}$ 5, 6, 7, 7.5, 8, 8.5, 9, 9.5, 10, 11 and 12 was assessed on TSA buffered with citric acid/NaOH (for $\mathrm{pH} 5$ and 6), phosphate (pH 7 and 8), glycine/ $\mathrm{NaOH}$ (for $\mathrm{pH} 9$ and 10) or Tris (for $\mathrm{pH} 11$ and 12).

Fatty acid methyl esters were prepared and analysed by using the Sherlock Microbial Identification System (MIDI) according to the protocol described by Agilent Technologies. For this purpose, strain AMV16 ${ }^{\mathrm{T}}$ and $M$. tractuosa DSM $4126^{\mathrm{T}}$ were grown on marine agar 2216 (Difco) at $30{ }^{\circ} \mathrm{C}$ for 2 days. Polar lipids were extracted and analysed according to the method described by Komagata \& Suzuki (1987). Menaquinones and polar lipids were determined from freeze-dried cells. Menaquinones were extracted as described by Collins et al. (1977) and analysed by HPLC (Groth et al., 1997). DNA was isolated according to the procedure of Marmur (1961) and the G $+C$ content was determined from melting point $\left(T_{\mathrm{m}}\right)$ curves (Sly et al., 1986) obtained by using a Lambda 2 UV-Vis spectrophotometer (Perkin Elmer) equipped with the Templab 2.0 software package (Perkin Elmer). Escherichia coli DNA was used as a standard in determining the DNA G $+\mathrm{C}$ content. For 16S rRNA gene sequencing, DNA was prepared using the Mo Bio microbial DNA isolation kit (Mo Bio Laboratories Inc.) and sequenced as described previously (Lane, 1991). The resultant almost-complete sequence of the 16S rRNA gene contained $1502 \mathrm{nt}$. The $16 \mathrm{~S}$ rRNA gene sequence of the isolate was subjected to BLAST sequence similarity search (Altschul et al., 1990) and EzTaxon (Chun et al., 2007) to identify the nearest taxa. All 16S rRNA gene sequences of members of the family 'Flammeovirgaceae' were downloaded from the NCBI database (http://www. ncbi.nlm.nih.gov) and aligned using the CLUSTAL_X program (Thompson et al., 1997) and the alignment was then corrected manually. Phylogenetic trees were constructed using two tree-making algorithms, the maximumlikelihood method using the PhyML program (Guindon \& Gascuel, 2003) and the neighbour-joining method (Saitou \& Nei, 1987) using the PHYLIP package, version 3.5 (Felsenstein, 1993), and the resultant tree topologies were evaluated by bootstrap analysis based on 1000 resamplings using the SEQBOOT and CONSENSE programs in the PHYLIP package. Pairwise evolutionary distances were computed using the DNADIST program with Kimura's twoparameter model as developed by Kimura (1980).

Cells of strain $\mathrm{AMV}^{\mathrm{T}}{ }^{\mathrm{T}}$ were Gram-negative, non-motile rods, $0.5-0.7 \mu \mathrm{m}$ wide and 1-3 $\mathrm{m}$ long (Fig. 1), and multiplied by binary fission. Colonies were circular, 0.5$1.5 \mathrm{~mm}$ in diameter, smooth, shiny, pale orange, translucent and raised with entire margins on marine agar. The strain was positive for catalase, oxidase, ornithine decarboxylase, lysine decarboxylase and lipase and negative for DNase, gelatinase and urease. Strain AMV16 ${ }^{\mathrm{T}}$ reduced nitrate and hydrolysed aesculin but not starch, cellulose or casein. It was negative for indole production. Growth was observed at $18-37^{\circ} \mathrm{C}$ with optimum growth at $30-37{ }^{\circ} \mathrm{C}$, at $0-5 \%(\mathrm{w} / \mathrm{v}) \mathrm{NaCl}$, with optimum growth at $2-3 \%$, and at $\mathrm{pH} \mathrm{6-8,} \mathrm{with} \mathrm{optimum} \mathrm{growth} \mathrm{at} \mathrm{pH}$ 7.5. Other characteristics are presented in Table 1 . The cellular fatty acid composition of strain AMV16 ${ }^{\mathrm{T}}$ showed a spectrum of 12 fatty acids with a pronounced dominance $(>4 \%)$ of anteiso- $C_{11: 0}$, anteiso- $C_{12: 0}, C_{12: 0}$, iso- $C_{15: 0}$, iso- $C_{19: 0}$, $\mathrm{C}_{13: 1}$, iso- $\mathrm{C}_{15: 1} \mathrm{G}$, iso- $\mathrm{C}_{16: 1} \mathrm{G}$ and summed feature 5 (anteiso- $\mathrm{C}_{18: 0}$ and/or $\mathrm{C}_{18: 2} \omega 6,9 c$ ) (Table 2). Saturated fatty acids constituted $62.3 \%$ of the total fatty acids. When compared with $M$. tractuosa DSM $4126^{\mathrm{T}}$, the number of fatty acids detected in strain AMV16 ${ }^{\mathrm{T}}$ was greater and the composition differed considerably (Table 2). The menaquinone present in $\mathrm{AMV} 16^{\mathrm{T}}$ was MK-4; diphosphatidylglycerol and phosphatidylethanolamine made up the phospholipids. Other characteristics are listed in the species description. The DNA G + C content of strain AMV16 ${ }^{\mathrm{T}}$ was $50.9 \mathrm{~mol} \%$.

Phylogenetic relationships of strain AMV16 ${ }^{\mathrm{T}}$ were ascertained based on 16S rRNA gene sequence similarity with other strains using the BLAST sequence similarity search (NCBI BLAST/EzTaxon). The results indicated that, at the $16 \mathrm{~S}$ rRNA gene sequence level, strain $\mathrm{AMV} 16^{\mathrm{T}}$ was close to the phylogenetic neighbours $M$. tractuosa and M. sericea, with pairwise sequence similarity to the type strains of 89.9-90.0\%. Phylogenetic analyses based on maximumlikelihood and neighbour-joining trees further indicated that strain AMV16 ${ }^{T}$ clustered with $M$. tractuosa and $M$. sericea at a phylogenetic distance of $14.6 \%$, distinct from clades representing the genera Fabibacter, Flammeovirga,

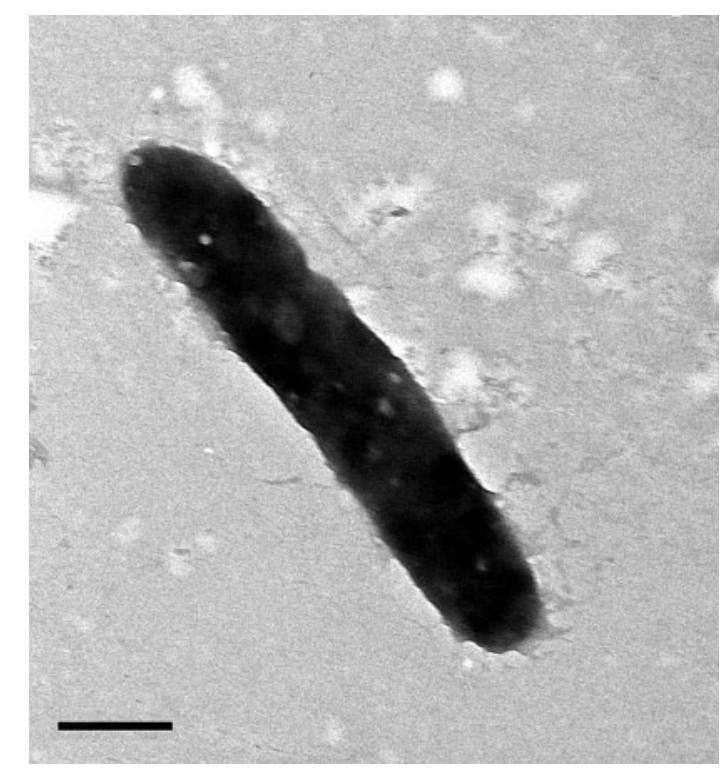

Fig. 1. Electron micrograph of a negatively stained cell of strain AMV16 ${ }^{\top}$. Bar, $0.5 \mu \mathrm{m}$. 
Table 1. Features that distinguish strain $A M V 16^{\top}$ from the closely related M. tractuosa DSM $4126^{\top}$

Data for both strains are from the present study. Both strains were rod-shaped, positive for oxidase and hydrolysis of aesculin and Tween 20, negative for hydrolysis of agar, casein, cellulose, DNA, starch and urea, phenylalanine deamination, $\mathrm{H}_{2} \mathrm{~S}$ production, citrate utilization, Voges-Proskauer and methyl red tests and indole production and do not utilize glycine, leucine, isoleucine, phenylalanine, tyrosine, tryptophan, aspartic acid, glutamic acid, threonine, histidine, methionine, glutamine or serine. Both strains are resistant to $(\mu \mathrm{g}$ per disc) amikacin (30), cefazolin (30), co-trimoxazole (25), kanamycin (30), lomefloxacin (30), nalidixic acid (30), nitrofurantoin (300), penicillin $G(10)$, streptomycin (10), tetracycline (30) and tobramycin (10) and sensitive to cefuroxime sodium salt (30), cefotaxime (30) and chloramphenicol (30). Both strains show optimum growth in $2-3 \%(\mathrm{w} / \mathrm{v}) \mathrm{NaCl}$ and grow at $18-37{ }^{\circ} \mathrm{C}$ with optimum growth at $30-37{ }^{\circ} \mathrm{C}$. + , Positive; - , negative; w, weak; $\mathrm{R}$, resistant; $\mathrm{s}$, sensitive.

\begin{tabular}{|c|c|c|}
\hline Characteristic & $\operatorname{AMV}^{1} 6^{\mathrm{T}}$ & $\begin{array}{l}\text { M. tractuosa } \\
\text { DSM } 4126^{\mathrm{T}}\end{array}$ \\
\hline Cell size $(\mu \mathrm{m})$ & $0.5-0.7 \times 1-3$ & $0.4-0.5 \times 10-50$ \\
\hline Colony colour & Pale orange & Dark orange \\
\hline $\begin{array}{l}\mathrm{NaCl} \text { concentration for } \\
\text { growth }(\%, \mathrm{w} / \mathrm{v})\end{array}$ & $0-5$ & $0.5-6$ \\
\hline $\mathrm{pH}$ range for growth & $6-8$ & $7.0-7.5$ \\
\hline Catalase & + & $\mathrm{w}$ \\
\hline Lysine decarboxylase & + & - \\
\hline Ornithine decarboxylase & + & - \\
\hline Nitrate reduction & + & - \\
\hline \multicolumn{3}{|l|}{ Hydrolysis of: } \\
\hline Gelatin & - & + \\
\hline Tweens 40,60 and 80 & + & - \\
\hline \multicolumn{3}{|l|}{ Acid production from: } \\
\hline Glucosamine & + & $\mathrm{W}$ \\
\hline Ribose & + & - \\
\hline \multicolumn{3}{|l|}{ Utilization of: } \\
\hline Glucosamine & + & $\mathrm{w}$ \\
\hline Ribose & + & - \\
\hline Alanine & - & $\mathrm{W}$ \\
\hline Valine & - & + \\
\hline Arginine & - & + \\
\hline Cysteine & - & $\mathrm{w}$ \\
\hline \multicolumn{3}{|l|}{$\begin{array}{l}\text { Antibiotic susceptibility } \\
\text { (per disc) }\end{array}$} \\
\hline Ampicillin $(10 \mu \mathrm{g})$ & $\mathrm{R}$ & s \\
\hline Cefoperazone $(75 \mu \mathrm{g})$ & s & $\mathrm{R}$ \\
\hline Ciprofloxacin $(5 \mu \mathrm{g})$ & s & $\mathrm{R}$ \\
\hline Erythromycin $(15 \mu \mathrm{g})$ & $\mathrm{R}$ & s \\
\hline Norfloxacin $(10 \mu \mathrm{g})$ & s & $\mathrm{R}$ \\
\hline Vancomycin $(30 \mu \mathrm{g})$ & $\mathrm{R}$ & s \\
\hline Major fatty acids* & $\begin{array}{c}\text { ai- } C_{11: 0}, \text { ai }-C_{12: 0}, \\
C_{12: 0}, i-C_{15: 0}, i- \\
C_{19: 0}, C_{13: 1}, i-C_{15: 1} \\
\text { G, i- } C_{16: 1} \text { G, SF5 }\end{array}$ & $\begin{array}{c}\mathrm{i}-\mathrm{C}_{15: 0} \\
\mathrm{C}_{15: 1} \omega 8 c, \mathrm{i}- \\
\mathrm{C}_{15: 1} \mathrm{G}\end{array}$ \\
\hline Phospholipids $\dagger$ & DPG, PE & $\mathrm{PC}, \mathrm{PE}$ \\
\hline Major quinone & MK-4 & MK-7 \\
\hline
\end{tabular}

Table 1. cont.

\begin{tabular}{|c|c|c|}
\hline Characteristic & AMV16 $^{\mathrm{T}}$ & $\begin{array}{c}\text { M. tractuosa } \\
\text { DSM } 4126^{T}\end{array}$ \\
\hline $\begin{array}{l}\text { DNA G + C content } \\
(\mathrm{mol} \%)\end{array}$ & 50.9 & 35.8 \\
\hline
\end{tabular}

*ai, Anteiso-branched; i, iso-branched; SF5, summed feature 5 (anteiso- $\mathrm{C}_{18: 0}$ and/or $\mathrm{C}_{18: 2} \omega 6,9 c$ ).

$\nmid$ DPG, Diphosphatidylglycerol; PC, phosphatidylcholine; PE, phosphatidylethanolamine.

Flexithrix, Limibacter, Marinoscillum, Perexilibacter, Persicobacter, Rapidithrix, Reichenbachiella, Roseivirga and Thermonema (Fig. 2).

Strain AMV16 ${ }^{\mathrm{T}}$ differs from all the other genera in the family 'Flammeovirgaceae' by a number of characteristics (Table 3). Based on the 16S rRNA gene sequence phylogeny, the nearest genus in the family 'Flammeovirgaceae' was

Table 2. Fatty acid profiles of strain $\mathrm{AMV} 6^{\top}$ and $M$. tractuosa DSM $4126^{\top}$

Data for both strains are from the present study following growth on marine agar at $30{ }^{\circ} \mathrm{C}$ for 2 days. Results are percentages of the total fatty acids. ND, Not detected.

\begin{tabular}{|c|c|c|}
\hline Fatty acid & Strain AMV16 ${ }^{\mathrm{T}}$ & $\begin{array}{c}\text { M. tractuosa } \\
\text { DSM } 4126^{\mathrm{T}}\end{array}$ \\
\hline $\mathrm{C}_{10: 0}$ & $\mathrm{ND}$ & 0.7 \\
\hline iso- $\mathrm{C}_{11: 0}$ & $\mathrm{ND}$ & 3.8 \\
\hline anteiso- $\mathrm{C}_{11: 0}$ & 5.4 & 0.4 \\
\hline $\mathrm{C}_{11: 0}$ & ND & 0.4 \\
\hline anteiso- $\mathrm{C}_{12: 0}$ & 4.1 & ND \\
\hline $\mathrm{C}_{12: 0}$ & 7.0 & 0.9 \\
\hline iso- $\mathrm{C}_{13: 0}$ & ND & 2.6 \\
\hline $\mathrm{C}_{13: 1}$ & 13.8 & 2.2 \\
\hline iso- $\mathrm{C}_{15: 0}$ & 14.4 & 41.8 \\
\hline anteiso- $\mathrm{C}_{15: 0}$ & 3.4 & 1.1 \\
\hline iso- $\mathrm{C}_{15: 1} \mathrm{G}$ & 15.9 & 35.8 \\
\hline $\mathrm{C}_{15: 1} \omega 8 c$ & ND & 4.0 \\
\hline iso- $\mathrm{C}_{16: 0}$ & $\mathrm{ND}$ & 1.8 \\
\hline anteiso- $\mathrm{C}_{16: 0}$ & 3.0 & $\mathrm{ND}$ \\
\hline $\mathrm{C}_{16: 0}$ & 2.6 & 0.7 \\
\hline iso- $\mathrm{C}_{16: 1} \mathrm{G}$ & 11.1 & 0.7 \\
\hline iso- $\mathrm{C}_{17: 0}$ & $\mathrm{ND}$ & 0.8 \\
\hline anteiso- $\mathrm{C}_{17: 0}$ & 3.7 & $\mathrm{ND}$ \\
\hline anteiso- $\mathrm{C}_{17: 1} \omega 9 c$ & $\mathrm{ND}$ & 0.9 \\
\hline iso- $\mathrm{C}_{19: 0}$ & 9.7 & ND \\
\hline Summed feature $5^{\star}$ & 5.9 & ND \\
\hline
\end{tabular}

* Summed features are groups of two or three fatty acids that cannot be separated by GLC using the MIDI System. Summed feature 5 contained anteiso- $\mathrm{C}_{18: 0}$ and/or $\mathrm{C}_{18: 2} \omega 6,9 c$. 


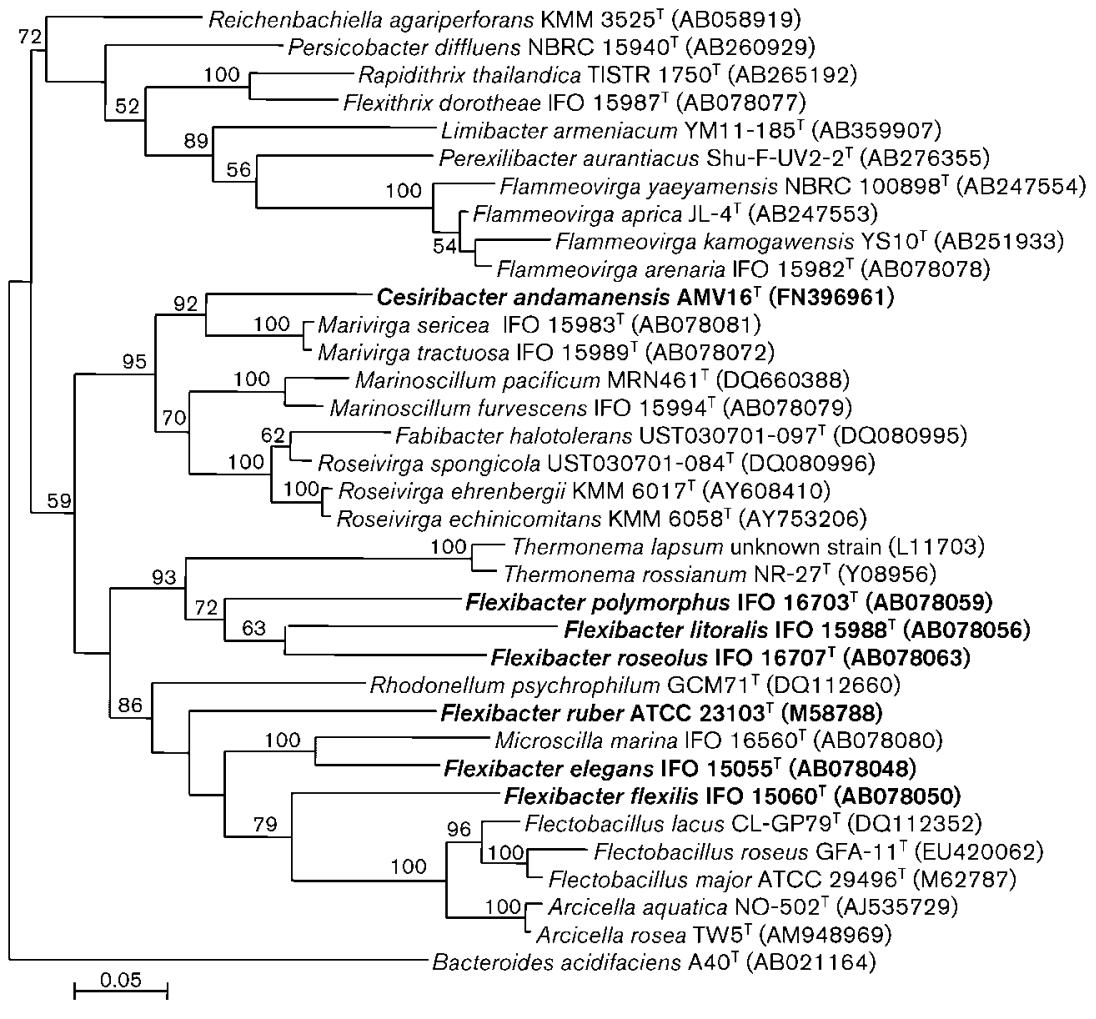

Fig. 2. Phylogenetic tree based on $16 \mathrm{~S}$ rRNA gene sequences showing relationships of strain $\mathrm{AMV} 16^{\top}$ to members of the Cytophagaceae. The tree was reconstructed using the maximum-likelihood method. Members of the genus Flexibacter are highlighted in bold, in addition to strain AMV16 ${ }^{\top}$. Numbers at nodes are bootstrap percentages from 1000 resamplings. Bar, 0.05 substitutions per nucleotide position.
Marivirga. Strain AMV16 ${ }^{\mathrm{T}}$ differed from the genus Marivirga with respect to characteristics such as major fatty acids and DNA G $+\mathrm{C}$ content (Table 3 ).

Strain AMV16 ${ }^{\mathrm{T}}$ could also be differentiated phenotypically from the closest related species M. tractuosa, the type species of the genus Marivirga (Table 3). For instance, AMV16 ${ }^{\mathrm{T}}$ differed from $M$. tractuosa DSM $4126^{\mathrm{T}}$ in colony colour, cell size, tolerance of salt, some enzyme activities, hydrolysis of gelatin and Tweens 40, 60 and 80, acid production from carbohydrates, utilization of various carbon sources, antibiotic susceptibility, major fatty acids, phospholipids and DNA G $+\mathrm{C}$ content (Table 1). Thus, the cumulative differences that strain AMV $16^{\mathrm{T}}$ exhibits from the species of Marivirga unambiguously support the creation of a new genus and species to accommodate strain $\mathrm{AMV}^{\mathrm{T}}{ }^{\mathrm{T}}$, for which the name Cesiribacter andamanensis gen. nov., sp. nov. is proposed.

Phylogenetic analysis of taxa related to the genus Flexibacter of the family Cytophagaceae indicated that the genus Flexibacter is polyphyletic and its species cluster randomly with different genera (Fig. 2). For instance, Flexibacter flexilis IFO $15060^{\mathrm{T}}$ formed a clade with the genera Flectobacillus and Arcicella, Flexibacter ruber ATCC $23103^{\mathrm{T}}$ and Flexibacter elegans IFO $15055^{\mathrm{T}}$ formed a clade with the genera Rhodonellum and Microscilla and the type strains of three other species of Flexibacter, namely Flexibacter roseolus IFO $16707^{\mathrm{T}}$, Flexibacter litoralis IFO $15988^{\mathrm{T}}$ and Flexibacter polymorphus IFO $16703^{\mathrm{T}}$, formed a distinct clade and branched from the two major clades within the family Cytophagaceae. M. tractuosa, which was formerly a member of the genus Flexibacter, was recently transferred to the new genus Marivirga based on a polyphasic taxonomic approach (Nedashkovskaya et al., 2010). Thus, it is evident the genus Flexibacter remains polyphyletic and there is a continuing need to re-evaluate its taxonomic status based on polyphasic taxonomy and comparison with all taxa within the family Cytophagaceae.

\section{Description of Cesiribacter gen. nov.}

Cesiribacter [Ce.si.ri.bac'ter. N.L. n. cesirum arbitrary name derived from the acronym CSIR (Council of Scientific and Industrial Research); N.L. masc. n. bacter rod; N.L. masc. n. Cesiribacter rod named in honour of the CSIR, the national funding agency which has augmented science and technology development in India].

Cells are aerobic and non-motile, Gram-staining-negative, rod-shaped and positive for catalase, oxidase, ornithine decarboxylase, lysine decarboxylase and lipase and negative for DNase, gelatinase and urease. The major fatty acids are anteiso- $\mathrm{C}_{11: 0}$, anteiso- $\mathrm{C}_{12: 0}, \mathrm{C}_{12: 0}$, iso- $\mathrm{C}_{15: 0}$, iso- $\mathrm{C}_{19: 0}$, $\mathrm{C}_{13: 1}$, iso- $\mathrm{C}_{15: 1} \mathrm{G}$, iso- $\mathrm{C}_{16: 1} \mathrm{G}$ and summed feature 5 (anteiso- $\mathrm{C}_{18: 0}$ and/or $\mathrm{C}_{18: 2} \omega 6,9 c$ ). MK-4 is the predominant respiratory quinone. The phospholipids include diphosphatidylglycerol and phosphatidylethanolamine. The genomic DNA G $+C$ content of the type strain of the type species is $50.9 \mathrm{~mol} \%$. The genus is a member of the family 'Flammeovirgaceae', class Sphingobacteria, phylum Bacteroidetes. The type species is Cesiribacter andamanensis. 
Table 3. Distinguishing features of strain $\mathrm{AMV}_{16}{ }^{\top}$ and other genera within the family 'Flammeovirgaceae'

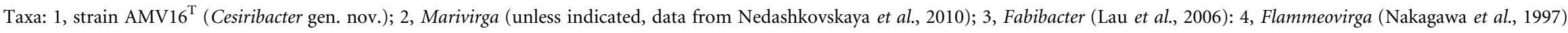

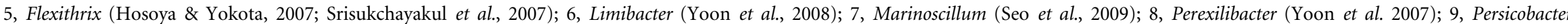

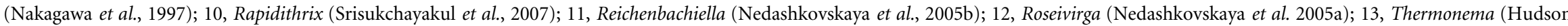
et al. 1989). v, Variable; NA, no data available.

\begin{tabular}{|c|c|c|c|c|c|c|c|c|c|c|c|c|c|}
\hline Characteristic & 1 & 2 & 3 & 4 & 5 & 6 & 7 & 8 & 9 & 10 & 11 & 12 & 13 \\
\hline Cell shape* & $\mathrm{R}$ & $\mathrm{R}$ & $\mathrm{CR}$ & LR & $\mathrm{F}$ & $\mathrm{R}$ & FTR & $\mathrm{R}$ & $\mathrm{R}$ & $\mathrm{F}$ & $\mathrm{R}$ & $\mathrm{R}$ & $\mathrm{F}$ \\
\hline Motility & - & Gliding & Gliding & Gliding & Gliding & Gliding & Gliding & Gliding & Gliding & Gliding & + & - & Gliding \\
\hline $\begin{array}{l}\text { Endospore } \\
\text { formation }\end{array}$ & - & - & $\mathrm{NA}$ & $\mathrm{NA}$ & $\mathrm{NA}$ & - & $\mathrm{NA}$ & - & - & - & - & - & $\mathrm{NA}$ \\
\hline Pigmentation $\dagger$ & o & $\mathrm{O} / \mathrm{Y}$ & $\mathrm{P}$ & $\mathrm{O}-\mathrm{RO}$ & GY & o & $\mathrm{O} / \mathrm{AP}$ & o & $\mathrm{p}-\mathrm{O}$ & OG & o & $\mathrm{O} / \mathrm{P}$ & $\mathrm{Y}$ \\
\hline $\begin{array}{l}\text { Oxidase/catalase } \\
\text { Major fatty acids } \ddagger\end{array}$ & $\begin{array}{c}+/+ \\
\text { ai- } C_{11: 0}, \text { ai- }-C_{12: 0}, \\
C_{12: 0}, i-C_{15: 0}, \\
\text { i- }-C_{19: 0}, C_{13: 1}, \\
\text { i- } C_{15: 1 G}, i-C_{18: 1 G}, \\
\text { SF5 }\end{array}$ & $\begin{array}{l}+/+ \\
\mathrm{i}-\mathrm{C}_{15: 0}, \\
\mathrm{i}-\mathrm{C}_{15: 1} \mathrm{G}, \\
\mathrm{C}_{15: 1} \omega 8 \mathrm{cS}\end{array}$ & 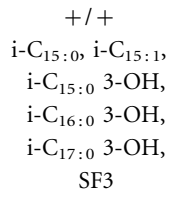 & $\begin{array}{c}\mathrm{v} / \mathrm{v} \\
\mathrm{i}-\mathrm{C}_{15: 0}, \\
\mathrm{C}_{20: 4} \omega 6,9,12,15 c, \\
\mathrm{C}_{16: 0} 3-\mathrm{OH}\end{array}$ & $\begin{array}{c}\mathrm{NA} /- \\
\mathrm{C}_{16: 1} \omega 5 c, \mathrm{i}-\mathrm{C}_{15: 0} \\
3-\mathrm{OH}, \mathrm{i}-\mathrm{C}_{17: 0} \\
3-\mathrm{OH}, \mathrm{i}-\mathrm{C}_{15: 0} \\
\text { 3-OH, } \mathrm{C}_{16: 0}\end{array}$ & $\begin{array}{c}-/+ \\
\text { i-C } \mathrm{C}_{15: 0} \\
\mathrm{C}_{16: 1} \omega 7 c\end{array}$ & $\begin{array}{c}+/+ \\
\mathrm{C}_{16: 1} \omega 5 c \\
\mathrm{SF} 3\end{array}$ & $\begin{array}{c}+/+ \\
\text { i- } \mathrm{C}_{15: 0} \\
\mathrm{C}_{16: 1} \omega 7 c \\
\mathrm{C}_{16: 1} \omega 5 c\end{array}$ & $\begin{array}{c}+/- \\
\text { i- } \mathrm{C}_{17: 1}, \mathrm{C}_{16: 0} \\
\mathrm{i}_{-\mathrm{C}_{18: 1}} 3-\mathrm{OH}, \\
\text { i- } \mathrm{C}_{17: 0}\end{array}$ & $\begin{array}{c}\text { +/NA } \\
\mathrm{C}_{16: 1} \omega 5 c \text {; i- } \mathrm{C}_{15: 0} \\
3-\mathrm{OH} \mathrm{i}-\mathrm{C}_{17: 0} \\
3-\mathrm{OH}, \mathrm{i}-\mathrm{C}_{15: 0} \\
3-\mathrm{OH}, \mathrm{C}_{16: 0}\end{array}$ & $\begin{array}{c}+/+ \\
\text { i- } C_{15: 0} \\
C_{16: 1} \omega 9\end{array}$ & $\begin{array}{c}+/+ \\
\text { i- } C_{15: 1}, \\
\text { i- } C_{15: 0}, \\
\text { ai- } C_{15: 0}, \\
\text { i- } C_{17: 0} \\
3-\mathrm{OH}\end{array}$ & $\begin{array}{r}+/+ \\
\text { i- } \mathrm{C}_{15: 0}, \\
\mathrm{i}-\mathrm{C}_{17: 0} \\
3-\mathrm{OH}\end{array}$ \\
\hline $\begin{array}{l}\text { DNA G }+\mathrm{C} \\
\text { content }(\mathrm{mol} \%)\end{array}$ & 50.9 & $36-37$ & 42.5 & $31-36$ & 37 & 27.9 & $41-44$ & 43 & $40-42$ & $40-43$ & 44.5 & $40.1-43.7$ & $47-50.9$ \\
\hline Isolation sourcell & s & FW & MSP & M & sss & MS & MSP & SW & M & SS & sw & GA & HS \\
\hline
\end{tabular}

${ }^{*} \mathrm{CR}$, Curved rod; F, filament; FTR, flexible thread-like rod; LR, long rod; R, rod.

$\dagger$ AP, Apricot; GY, golden yellow; O, orange; OG, olive grey; P, pink; RO, reddish orange; Y, yellow.

¥ai, Anteiso-branched; i, iso-branched; SF3, summed feature 3 (iso- $\mathrm{C}_{15: 0} 2-\mathrm{OH}$ and/or $\mathrm{C}_{16: 1} \omega 7 \mathrm{c}$ ); SF5, summed feature 5 (anteiso- $\mathrm{C}_{18: 0}$ and/or $\mathrm{C}_{18: 2} \omega 6,9 c$ ).

§Data from this study for M. tractuosa DSM $4126^{\mathrm{T}}$.

IFW, Fresh water; GA, green alga; HS, hot spring; M, marine; MS, marine sediment; MSP, marine sponge; s, soil; ss, sea shell; sss, seashore silt; sW, seawater. 


\section{Description of Cesiribacter andamanensis sp. nov.}

Cesiribacter andamanensis (an.da.ma.nen'sis. N.L. masc. adj. andamanensis of or belonging to Andaman Islands, India, referring to the isolation of the type strain).

Displays the following properties in addition to those given in the genus description. Cells are $0.5-0.7 \mu \mathrm{m}$ wide and 1$3 \mu \mathrm{m}$ long, occur singly and multiply by binary fission. Colonies on marine agar are circular, $0.5-1.5 \mathrm{~mm}$ in diameter, smooth, shiny, pale orange, translucent and raised with entire margins. Grows at $18-37{ }^{\circ} \mathrm{C}$ with an optimum temperature of $30-37{ }^{\circ} \mathrm{C}$ and tolerates up to $5.0 \% \mathrm{NaCl}(\mathrm{w} / \mathrm{v})$. Grows at $\mathrm{pH} 6-8$. Tryptophan deaminase activity is not present. Indole is not produced. The methyl red and Voges-Proskauer reactions are negative. Starch and casein are not hydrolysed but Tweens 20, 40, 60 and 80 and aesculin are hydrolysed. Nitrate is reduced and $\mathrm{H}_{2} \mathrm{~S}$ gas is not produced. Produces acid from glucosamine and ribose but not from L- or D-arabinose, xylose, rhamnose, cellobiose, melibiose, sucrose, raffinose, trehalose, glucose, lactose, maltose, fructose, galactose, mannose, inulin, mannitol, methyl $\alpha$-D-glucoside, melezitose, methyl $\alpha$-D-mannoside, malonate, adonitol, sodium gluconate, glycerol, salicin, dulcitol, inositol, sorbitol or xylitol after 1 week of incubation at optimum temperature and $\mathrm{pH}$. Assimilates glucosamine and ribose but not L- or D-arabinose, xylose, rhamnose, cellobiose, melibiose, sucrose, raffinose, trehalose, glucose, lactose, maltose, fructose, galactose, mannose, inulin, mannitol, methyl $\alpha$-D-glucoside, melezitose, methyl $\alpha$-D-mannoside, malonate, adonitol, sodium gluconate, glycerol, salicin, dulcitol, inositol, sorbitol or xylitol. Susceptible to ( $\mu \mathrm{g}$ per disc unless indicated) cefotaxime (30), chloramphenicol (30), ciprofloxacin (5), cefuroxime (30) and cefoperazone (75) and resistant to amikacin (30), ampicillin (10), cefazolin (30), colistin (10), co-trimoxazole (25), erythromycin (15), penicillin $\mathrm{G}$ (10), polymyxin B (50 U), kanamycin (30), lomefloxacin (30), nalidixic acid (30), nitrofurantoin (300), streptomycin (10), tetracycline (30), tobramycin (10) and vancomycin (30). The cellular fatty acid composition of the type strain is detailed in Table 2.

The type strain, AMV16 ${ }^{\mathrm{T}}\left(=\mathrm{DSM} 22818^{\mathrm{T}}=\mathrm{CCUG}\right.$ $58431^{\mathrm{T}}$ ), was isolated from a soil sample collected from a mud volcano on Baratang Island, Middle Andamans, India.

\section{Acknowledgements}

S.S. is thankful to the National Centre for Antarctic and Ocean Research, Goa, the Department of Biotechnology, New Delhi, and the CSIR Network Project on Biodiversity for funding. T.N.R.S. acknowledges the CSIR, Government of India, for the award of a Research Associateship.

\section{References}

Altschul, S. F., Gish, W., Miller, W., Myers, E. W. \& Lipman, D. J. (1990). Basic local alignment search tool. J Mol Biol 215, 403-410.
Chun, J., Lee, J.-H., Jung, Y., Kim, M., Kim, S., Kim, B. K. \& Lim, Y. W. (2007). EzTaxon: a web-based tool for the identification of prokaryotes based on $16 \mathrm{~S}$ ribosomal RNA gene sequences. Int J Syst Evol Microbiol 57, 2259-2261.

Collins, M. D., Pirouz, T., Goodfellow, M. \& Minnikin, D. E. (1977). Distribution of menaquinones in actinomycetes and corynebacteria. J Gen Microbiol 100, 221-230.

Felsenstein, J. (1993). PHYLIP (phylogeny inference package), version 3.5.1. Department of Genome Sciences, University of Washington, Seattle, USA.

Groth, I., Schumann, P., Rainey, F. A., Martin, K., Schuetze, B. \& Augsten, K. (1997). Demetria terragena gen. nov., sp. nov., a new genus of actinomycetes isolated from compost soil. Int J Syst Bacteriol 47, 1129-1133.

Guindon, S. \& Gascuel, O. (2003). A simple, fast, and accurate algorithm to estimate large phylogenies by maximum likelihood. Syst Biol 52, 696-704.

Hosoya, S. \& Yokota, A. (2007). Reclassification of Flexibacter aggregans (Lewin 1969) Leadbetter 1974 as a later heterotypic synonym of Flexithrix dorotheae Lewin 1970. Int J Syst Evol Microbiol 57, 1086-1088.

Hudson, J. A., Schofield, K. M., Morgan, H. W. \& Daniel, R. M. (1989). Thermonema lapsum gen. nov., sp. nov., a thermophilic gliding bacterium. Int J Syst Bacteriol 39, 485-487.

Kimura, M. (1980). A simple method for estimating evolutionary rates of base substitutions through comparative studies of nucleotide sequences. J Mol Evol 16, 111-120.

Komagata, K. \& Suzuki, K. (1987). Lipid and cell wall analysis in bacterial systematics. Methods Microbiol 19, 161-207.

Lane, D. J. (1991). 16S/23S rRNA sequencing. In Nucleic Acid Techniques in Bacterial Systematics, pp. 115-175. Edited by E. Stackebrandt \& M. Goodfellow. Chichester: Wiley.

Lányí, B. (1987). Classical and rapid identification methods for medically important bacteria. Methods Microbiol 19, 1-67.

Lau, S. C., Tsoi, M. M., Li, X., Plakhotnikova, I., Dobretsov, S., Wu, M., Wong, P. K., Pawlik, J. R. \& Qian, P. Y. (2006). Description of Fabibacter halotolerans gen. nov., sp. nov. and Roseivirga spongicola sp. nov., and reclassification of [Marinicola] seohaensis as Roseivirga seohaensis comb. nov. Int J Syst Evol Microbiol 56, 1059-1065.

Marmur, J. (1961). A procedure for the isolation of deoxyribonucleic acid from microorganisms. J Mol Biol 3, 208-218.

Nakagawa, Y., Hamana, K., Sakane, T. \& Yamasato, K. (1997). Reclassification of Cytophaga aprica (Lewin 1969) Reichenbach 1989 in Flammeovirga gen. nov. as Flammeovirga aprica comb. nov. and of Cytophaga diffluens (ex Stanier 1940; emend. Lewin 1969) Reichenbach 1989 in Persicobacter gen. nov. as Persicobacter diffluens comb. nov. Int J Syst Bacteriol 47, 220-223.

Nedashkovskaya, O. I., Kim, S. B., Lee, D. H., Lysenko, A. M., Shevchenko, L. S., Frolova, G. M., Mikhailov, V. V., Lee, K. H. \& Bae, K. S. (2005a). Roseivirga ehrenbergii gen. nov., sp. nov., a novel marine bacterium of the phylum 'Bacteroidetes', isolated from the green alga Ulva fenestrata. Int J Syst Evol Microbiol 55, 231-234.

Nedashkovskaya, O. I., Kim, S. B., Suzuki, M., Shevchenko, L. S., Lee, M. S., Lee, K. H., Park, M. S., Frolova, G. M., Oh, H. W. \& other authors (2005b). Pontibacter actiniarum gen. nov., sp. nov., a novel member of the phylum 'Bacteroidetes', and proposal of Reichenbachiella gen. nov. as a replacement for the illegitimate prokaryotic generic name Reichenbachia Nedashkovskaya et al. 2003. Int J Syst Evol Microbiol 55, 2583-2588.

Nedashkovskaya, O. I., Vancanneyt, M., Kim, S. B. \& Bae, K. S. (2010). Reclassification of Flexibacter tractuosus (Lewin 1969) Leadbetter 1974 and 'Microscilla sericea' Lewin 1969 in the genus 
Marivirga gen. nov. as Marivirga tractuosa comb. nov. and Marivirga sericea nom. rev., comb. nov. Int J Syst Evol Microbiol 60, 18581863.

Saitou, N. \& Nei, M. (1987). The neighbor-joining method: a new method for reconstructing phylogenetic trees. Mol Biol Evol 4, 406425.

Seo, H. S., Kwon, K. K., Yang, S. H., Lee, H. S., Bae, S. S., Lee, J. H. \& Kim, S. J. (2009). Marinoscillum gen. nov., a member of the family 'Flexibacteraceae', with Marinoscillum pacificum sp. nov. from a marine sponge and Marinoscillum furvescens nom. rev., comb. nov. Int J Syst Evol Microbiol 59, 1204-1208.

Sly, L. I., Blackall, L. L., Kraat, P. C., Tian-Shen, T. \& Sangkhobol, V. (1986). The use of second derivative plots for the determination of mol\% guanine plus cytosine of DNA by the thermal denaturation method. J Microbiol Methods 5, 139-156.

Smibert, R. M. \& Krieg, N. R. (1994). Phenotypic characterization. In Methods for General and Molecular Bacteriology, pp. 607-654. Edited by P. Gerhardt, R. G. E. Murray, W. A. Wood \& N. R. Krieg. Washington, DC: American Society for Microbiology.
Srisukchayakul, P., Suwanachart, C., Sangnoi, Y., Kanjana-Opas, A., Hosoya, S., Yokota, A. \& Arunpairojana, V. (2007). Rapidithrix thailandica gen. nov., sp. nov., a marine gliding bacterium isolated from samples collected from the Andaman sea, along the southern coastline of Thailand. Int J Syst Evol Microbiol 57, 2275-2279.

Thompson, J. D., Gibson, T. J., Plewniak, F., Jeanmougin, F. \& Higgins, D. G. (1997). The CLUSTAL_X windows interface: flexible strategies for multiple sequence alignment aided by quality analysis tools. Nucleic Acids Res 25, 4876-4882.

Yoon, J., Ishikawa, S., Kasai, H. \& Yokota, A. (2007). Perexilibacter aurantiacus gen. nov., sp. nov., a novel member of the family 'Flammeovirgaceae' isolated from sediment. Int J Syst Evol Microbiol 57, 964-968.

Yoon, J., Matsuo, Y., Kasai, H. \& Yokota, A. (2008). Limibacter armeniacum gen. nov., sp. nov., a novel representative of the family 'Flammeovirgaceae' isolated from marine sediment. Int J Syst Evol Microbiol 58, 982-986.

ZoBell, C. E. (1941). Studies on marine bacteria. I. The cultural requirements of heterotrophic aerobes. J Mar Res 4, 42-75. 